\title{
Impact of Syrian Refugees in Slovakia: Psychological Implications
}

\author{
5. Macurak (Shelby Macurak), D.J. West, Jr. (Daniel J. West, Jr.)
}

University of Scranton, PA., Master of Health Administration Graduate

Original Article Program, USA

\section{E-mail address:}

shelby.macurak@scranton.edu

\section{Reprint address:}

Shelby Macurak

University of Scranton

Scranton Hall

Scranton, PA. 18510

USA

Source: Clinical Social Work and Health Intervention

Pages: $23-27$
Volume: 10

Issue: 1

Cited references: 14

\section{Reviewers:}

Victor Namulanda Wanjala

Catholic University of Eastern Africa, Nairobi, Kenya

Gabriela Lezcano

University of California, San Francisco, USA

\section{Key words:}

Access to Mental Health. Syrian Refugees. Psychological Implications.

\section{Publisher:}

International Society of Applied Preventive Medicine i-gap

CSWHI 2019; 10(1): 23 - 27; DOI 10.22359/cswhi_10_1_03 @ 2019 Clinical Social Work and Health Intervention

\section{Abstract:}

Syrian refugees have become a topic of international discussion. The Syrian Civil War has led 13.1 million Syrians in need of human assistance from neighboring countries. While being in need of physical resources like food and shelter, refugees also experiences psychological implications in this difficult time. These psychological difficulties include depression and anxiety from losing loved ones and constantly being surrounded by a warzone. As a response, funding and other 
solutions have taken place through organizations like the Office of the United Nations High Commissioners for Refugees (UNHCR) and the European Union (EU). An example of a current solution would be the use of Emergency Transit Centers. While there are solutions in place, they lack in focus on mental health. The recommendations are to request more funding, request outside help with counselors or mental health advocates, and develop a realistic assessment of capacity.

\section{Introduction}

The Syrian Civil War officially began on March 15, 2011. The war broke out due to protestors demanding an end to authoritarian practices and the government's response was violent and extensive use of police, military, and paramilitary forces. Militias were formed by the citizens which expanded the conflict to a fully engulfed civil war (Britannica, 2018). Per the World Vision, 13.1 million Syrians need humanitarian assistance today (2018). The seven-year war has broken down the social and business ties that connected neighbors to their community. Buildings and homes have been destroyed including healthcare centers, hospitals, schools, utilities, and water and sanitation systems (World Vision, 2018). According to Skolnik, the situation in Syria is categorized as a complex humanitarian emergency which is a complex, multi-party, intra-state conflict resulting in a humanitarian disaster which can establish regional and international security threats (2016).

Today, 5.6 million Syrians have fled the country as refugees with 1.3 million who have requested asylum in Europe. According to Merriam-Webster (2018), asylum can be defined as protection given to political refugees by a nation. In Slovakia, there are a total of 923 refugees and 26 asylum seekers which accounts for less than $1 \%$ of the total population (Irish Examiner, 2018). This is a small percentage; however, it is important to keep in mind that it has the potential to grow and may result in undocumented refugees within the country. In
2017, Syrians have accounted for one-third of successful asylum cases (Globsec, 2017). Refugees come from Syria to Slovakia to be in a safer environment and seek employment for their future.

Politically, Slovakia acts as a transit country for the Syrians. This means that refugees are in Slovakia for a short period of time in between leaving Syria and going to their permanent country (Irish Examiner, 2018). In fall 2016, ten percent of Slovak citizens responded in a Eurobarometer survey. The results showed that Slovak citizens opposed the new refugees due to reasons including security risks, lack of cultural compatibility, and economic burden of the country (Globsec, 2017). They felt that resources were being taken away from Slovak citizens to be given to the refugees. This does not seem to be the case.

\section{Mental Implications \\ Children}

More than half of the refugees are displaced children. UNICEF defined a child displacement as the separation of children from their parents due to several varied reasons including civil war (2018). For a majority of them, war is all the children have ever known which has led to extreme effects. These extreme effects include diseases and malnutrition, child labor and child soldiers, child marriage and abuse, and lack of education opportunities. More than two million of Syrian children are out of school 
due to over one-third of the schools not being in use (World Vision, 2018).

\section{Adolescent and Adult}

A significant source of stress for refugees is the ongoing concern about the safety of their family members. The environment of a civil war can lead to the separation of family members. According to Hassan (2016), the mental implications include the feelings of estrangement, loss of identity, and struggling to adapt to life as refugees within a foreign country. Refugees are forced to leave their homeland and find shelter in foreign countries. Normally, the refugees are not welcomed by the other countries citizens. While it is not a good situation on either end, the discrimination against refugees contributes to stress and the feeling of isolation (Hassan et. al., 2016). The most common clinical disorders that arise from the mental implications include depression, prolonged grief disorder, post-traumatic stress disorder, and various forms of anxiety disorders (The Borgen Project, 2017). These implications derive from the emotional repercussions of living in a warzone and fleeing to surrounding countries for safety.

In the Borgen Project (2017), the issue is that the International Medical Corps found that Syrian refugees and internally displaced persons have extremely limited access to mental health facilities. Of these people, fifty-four percent suffer from severe emotional disorders like depression and anxiety. Internally displace persons (IDPs) can be defined as someone who is forced to flee their home during a complex humanitarian emergency but stay in the country in which they were living. This is a major issue because the mental difficulties of refugees are not being cared of due to a number of reasons. A key factor is that countries are dealing with a shortage of mental health providers due to the lack of mental health centers and professional. If countries do not have the ability to provide services or resources to their own citizens, how are they expected to provide them to others?

\section{Current Solutions}

The current Slovakia policy demonstrates a commitment to offering five-hundred and fifty university scholarships to refugees by 2021 (Globsec, 2017). This shows an educational assurance for refugees to have a brighter future and have the opportunity to provide for themselves and others through higher education. Other solutions within the policy include notable participation in Frontex and European Asylum Support Organization (EASO), funding to a number of organizations around this topic, and the operation of the Gabčíkovo center. This center hosts up to five hundred Syrian asylum seekers that are registered in Austria and are waiting for their application to be processed (Globsec, 2017). Lastly, there is the operation of the Emergency Transit Centers. Operated and financed by UNHCR and International Organization for Migration (IOM), these centers were built to provide temporary housing and facilitate their resettlement in safety. Currently, the capacity in a center is up to two-hundred and fifty refugees. During their six month stay, refugees prepare for resettlement through completing IOM health assessments, pre-departure orientation courses, and arrange international transport to their resettlement destinations. UNHCR provides the travel documents, health care and social services while the Slovak Republic grants visa upon their arrival and offers accommodation, meals, and basic hygiene items (WHO/Europe, 2018).

\section{Further Issues and Recommendations}

Further issues within Syrian refugees include insufficient housing, draining of Slovak Resources, and overall lack of mental 
health access for Slovak Citizens. Emergency transit centers only host up to two-hundred and fifty refugees when current data shows that there are nine-hundred and twenty-three refugees in the country. The center is unable to hold even half of the refugees that are in the Slovakia. Another issue listed is the perception that citizens have on the refugees. Many citizens feel that their resources are being drained due to providing for the refugees when that is not the case. As mention previously, majority of these movements for the refugees are funded by government or not-for-profit organizations. Lastly, the number of psychiatrists for the country is low. The country is experiencing a gap in mental health workers. If the country is unable to accurately treat their citizens when it comes to mental, they can not be expected to treat people outside of it (WHO 2018).

Ultimately, the focus should be shared between Slovak's citizens and the refugees. This could become more feasible through requesting more funding from the European Union and UNHCR. These two organizations are key players when it comes to the safety and future of refugees. If more wages are needed, more funds can be requested to cover the costs. The shelter situation can be solved through developing a realistic assessment of capacity. While the number of refugees is relatively low, it is important for the country to be able to do their part as a transit country. Through a development for realistic capacity, the country will be able to see if they need a second emergency transit center or other resources. Lastly, there should be a request for outside help with obtaining counselors or mental health advocates to assist with resolving the issue of access to mental health for refugees. Mental implications can have lifelong effects on a person when left untreated. It is important to have the ability to treat to better prepare this individuals for a bright future.

\section{References}

1. ASYLUM (2018, November 20) Retrieved from https://www.merriam-webster.com/dictionary/asylum.

2. FRELAK J S, JUHASZ A, JUNGWIRTH T, KUDZKO A, NIC M, ZGUT E (2017) Migration politics and policies in Central Europe. Migration Politics and Policies in Central Europe,24-33. Retrieved from https://www.globsec.org/wp-content/uploads/2017/08/migration_politics_and_policies_in_central_europe_web.pdf.

3. HASSAN G, VENTEVOGEL P, JEFEE-BAHLOUL H, BARKIL-OTEO A, KIRMAYER L J (2016) Mental health and psychosocial wellbeing of Syrians affected by armed conflict. Epidemiology and Psychiatric Sciences,25(02), 129-141. doi:10.1017/s2045796016000044.

4. M. OLAH (2016) Alternative child custody "Cochem's model". 1. ed. - Nadlac : Editura Ivan Krasko, 2016. - 221 - ISBN 9789731077060.

5. INTERNATIONAL ORGANIZATION FOR MIGRATION, REFUGEE AND ASYLUM ISSUES (2017, January 20) Slovakia Centre Sees Over 1,000 Refugees Resettled to USA, Canada, Norway[Press release]. Retrieved from https://www.iom.int/news/slovakia-centre-sees-over-1000-refugees-resettled-usa-canada-norway.

6. MIGRATION IN SLOVAKIA (2018, February 16) Retrieved from https:/www.iom. sk/en/migration/migration-in-slovakia.html.

7. O'DOHERTY C (2018, June 24) The migrant crisis and the very different approaches adopted by the 28 EU states. Retrieved from https://www.irishexaminer.com/ireland/the-migrant-crisis-and-the-very-different-approaches-adopted-by-the-28-eustates-472296.html.

8. SKOLNIK R (2016) Global Health 101. S.1.: Jones \& Bartlett Learning.

9. SYRIAN MENTAL HEALTH: COGNITIVE DEVELOPMENT OF SYRIA'S STATELESS CHILDREN (2017, June 07) 
Retrieved from https://borgenproject.org/ syrian-mental-health/.

10. SYRIAN REFUGEE CRISIS: FACTS, FAQS, AND HOW TO HELP (2018, August 02) Retrieved from https://www.worldvision.org/refugees-news-stories/syrian-refugee-crisis-facts.

11. TEN IMPORTANT FACTS TO KNOW ABOUT REFUGEES IN SLOVAKIA (2017, December 20) Retrieved from https:// borgenproject.org/ten-facts-refugees-in-slovakia/.

12. WORLD HEALTH ORGANIZATION/ EUROPE (2017, July 7) As refugee and migrant arrivals steadily increase, WHO invests in Europe's public health response[Press release]. Retrieved from http://www. euro.who.int/en/media-centre/sections/ press-releases/2017/as-refugee-and-migrant-arrivals-steadily-increase,-who-invests-in-europes-public-health-response.

13. WORLD HEALTH ORGANIZATION, REGIONAL OFFICE FOR EUROPE (2018, September 24) WHO School on Refugee and Migrant Health to build on existing capacities for providing care[Press release]. Retrieved from http://www.euro.who.int/en/ media-centre/sections/press-releases/2018/ who-school-on-refugee-and-migranthealth-to-build-on-existing-capacities-forproviding-care.

14. SYRIAN CIVIL WAR (2018, October 23) Retrieved from https://www.britannica. com/event/Syrian-Civil-War. 